\title{
Educational, Developer and Educative Duties in the Taxonomy of Training Objectives
}

\section{Deberes educativos, de desarrollo y educativos en la taxonomía de los objetivos de formación}

\author{
Alizade Sabina Hikmat \\ Azerbaijan State Pedagogical University, Azerbaijan \\ ORCID: https://orcid.org/0000-0003-0302-6786
}

Recibido 30-12-19 Revisado 11-01-19 Aprobado 14-02-20 En línea 27-02-20

*Correspondencia

Email: sabina.az@gmail.com

\section{Citar como:}

Sabina, A. (2020). Educational, Developer and Educative Duties in the Taxonomy of Training Objectives. Propósitos y Representaciones, 8(3). doi: http://dx.doi.org/10.20511/pyr2020.v8n3.465

(C) Universidad San Ignacio de Loyola, Vicerrectorado de Investigación, 2020. 


\section{Summary}

Every person has ability of creative thinking. However, not every person can be called a creative person. Creative people are those who are smart and possess the ability to grasp realities and reactions to these realities. At the same time, people who achieve extraordinary inventions or realize creative acts can also be referred to as creative people. The creative way of thinking is the type of thinking resulting from inventing new things or improving other actions. The creative way of thinking is used to generate a large number of ideas. The main characteristic of the creative way of thinking as an intellectual system is the ability to analyze any problem, establish systematic relations, reveal contrasts, find out ideal solutions for these contrasts, and forecast possible versions for the development. The research carried out once more proved that the creative way of thinking is important for life. From this reason, the society that wants to achieve great successes and implement creative potential must try to make students improve their creative ways of thinking.

Keywords: Creativity; Creative Way of Thinking; Taxonomy; Personal Qualities; Pedagogical Conception; Education

\section{Resumen}

Toda persona tiene capacidad de pensamiento creativo. Sin embargo, no todas las personas pueden llamarse personas creativas. Las personas creativas son aquellas que son inteligentes y poseen la capacidad de comprender las realidades y las reacciones a estas realidades. Al mismo tiempo, las personas que logran inventos extraordinarios o realizan actos creativos también pueden denominarse personas creativas. La forma creativa de pensar es el tipo de pensamiento resultante de inventar cosas nuevas o mejorar otras acciones. La forma creativa de pensar se utiliza para generar una gran cantidad de ideas. La característica principal de la forma creativa de pensar como sistema intelectual es la capacidad de analizar cualquier problema, establecer relaciones sistemáticas, revelar contrastes, encontrar soluciones ideales para estos contrastes y pronosticar posibles versiones para el desarrollo. La investigación llevada a cabo una vez más demostró que la forma creativa de pensar es importante para la vida. Por esta razón, la sociedad que quiere lograr grandes éxitos e implementar el potencial creativo debe tratar de hacer que los estudiantes mejoren sus formas creativas de pensar.

Palabras clave: Creatividad; Forma de Pensar Creativa; Taxonomía; Cualidades Personales; Concepción Pedagógica; Educación.

\section{Introducción}

Specific pedagogical conceptions are outlined throughout each stage of the development of a society. These conceptions not only reflect the pedagogical values of society from educating new generations perspective but also philosophical-psychological values (Alizada, 2001). As societies develop, new trends emerge in their education policies, stereotypes existing in previously formed pedagogical theories turn out to be obsolete, and when societies understand the necessity for new ones, new pedagogical conceptions emerge. Existing pedagogical conceptions in the world education history have developed in three directions:

1.Teaching-based education concepti

2.Development-based education conception;

3.Nurturing-based education conception (Pustamov, 2006). 
These pedagogical conceptions are completely different from the educational purposes points of view. Teaching-based education conception focuses on comprehension, but development-based education conception keeps the development factor in the center of attention. Nurturing-based education conception is included in enlightenment and development-based education conception contents and is realized in the formation of nurturing possibilities in the first case and the development of personality in the second case (Alizada, Alizada, Alizada ,2019).

Although teaching-based education conception and development-based education conception have developed parallelly in the world education history since ancient times, teachingbased education conception was used in wide geographical areas (Mahmudova, 2018). The main reason is very simple: the elimination of illiteracy was the main problem that thinkers, enlighteners, and teachers kept in the center of attention.

Based on the researches made by Jean Piaget (Piaget,1969), Lev Vygotsky (Vygotsky, 1934) Abraham Maslow (Maslow,1999), etc in the field of pedagogical psychology in the $20^{\text {th }}$ century, cognitive development became actual and was characterized as a psycho-pedagogical innovation. Scholars began to find ways to realize the educational objectives. Bloom taxonomy turned out to be the education conception of the century from realizing these objectives perspective.

\section{Argumentación}

\section{Cyberbullying (Ciberacoso)}

There are two versions of taxonomies named after Benjamin Samuel Bloom, an American educational psychologist. In the original version of the taxonomy, the cognitive domain is broken into the following six levels of objectives: Knowledge-Comprehension - Application-Analysis - Synthesis - Evaluation (Bloom, 1956).

The mentioned taxonomy that classifies educational learning objectives into levels of specificity and complexity can be divided into two parts. Nominally, the first can be called teaching-based education and the second part can be called development-based education (Alizada \& Sultanova, 2008).

Comprehension of knowledge by students is of a highly prioritized issue in the teachingbased education level. This level reflects the first three components in the taxonomy: knowledge, comprehension, and application. In the teaching-based education conception teaching, comprehension, and application were assessed as comprehension levels. In Didactica Magna, John Amos Comenius writes, "the scholar should be taught first to understand things, and then to remember them, and that no stress should be laid on the use of speech or pen, till after a training on the first two points"(M.W.Keatinge, 1907). Each stage is based on a specific goal. Within this idea, he put forward understanding, remembering, and applying as a goal of training. These levels (or these objectives) were considered enough for the comprehension of knowledge.

The comprehension of knowledge was the main objective of teaching-based education and based on memory. Memory is directly related to perceptive processes, for example, comprehension. Schools based on the teaching-based conception comprehended this well-rooted psychological fact as a memory factor. Memory is a psychological phenomenon. Memory phenomenon is attached much more importance in modern psychological researches and school processes, and mnemic processes are evaluated as important components of cognitive activities.

Teaching, comprehension, and application were the only levels in the teaching-based education conception. These objectives played the role of the foundation for the formation of 
cognitive activities. Especially, analysis and synthesis were mentioned separately in the aforementioned taxonomy. Analysis and synthesis are the main cognitive activities, and comparison, generalization, etc derive from these components.

In the 90s, Bloom's taxonomy was revised, and the second version was introduced. There are six levels of cognitive learning according to the revised version of Bloom's Taxonomy: Remember, Understand, Apply, Analyze, Evaluate, and Create (Bloom, 1994; Krathwohl, 2002).

In this version of the taxonomy, creativity issues were thrown light on. Probably, the main reason is the emergence of the creative way of thinking type as a result of researches conducted by psychologists between the 60s and the 90 . In the first half of the $20^{\text {th }}$ century, psychologists differentiated practical thinking, figurative thinking, and abstract thinking. In the second half of the century, as a result of researches carried out by psychologists, empirical thinking and theoretical thinking (Davidov, 1986), convergent and divergent thinking ${ }^{1}$ (Gilford, 1967; Drujinin, 2001), vertical and lateral thinking (Edvard de Bono, 1997) types became wide-ranged, and this process resulted with the revision of B.Bloom's taxonomy, offering wide options for the improvement of the creative way of thinking in education processes.

At all times, thinkers, enlighteners, and progressive teachers have attached importance to nurturing opportunities of lessons and used lessons within the framework of nurturing criteria. In the context of century-long experiences, the phrase the education must nurture students seems axiomatic (Alizada \& Alizada, 2008). From this perspective, a lesson can seem complete with the combination of teaching, developmental, and nurturing objectives. However, B.Bloom's taxonomy reflects only teaching and developmental objectives not focusing on nurturing objectives. On the other hand, nurturing characteristics of lessons require these objectives to be among prioritized issues (Qasimova \& Mahmudova, 2012).

The personality development problem is solved in the human relations context. In this aspect, classroom environments are good opportunities for personality development. Personality development is a time-consuming, complex, and contradictory process. In case this process is under the control of teachers, there are more possibilities for personality development. When approached from this aspect, nurturing characteristics of education and the importance for the third part of the taxonomy become actual. Psychologist Abdul Alizade has developed threecomponent educational taxonomy: $1^{\text {st }}$ part -learning; $2^{\text {nd }}$ part - development; $3^{\text {rd }}$ part - culture (Alizada \& Sultanova, 2008). Each part reflects the following elements: Learning - knowledge, ability, customs, remembering, understanding, and application; Development - analysis, synthesis, comparison, generalization, abstraction, cognitive peculiarities, cognitive and creative processes; Culture - the culture of feelings, communication culture, moral culture, volitional culture, national-moral culture, and secular culture (Alizada \& Sultanova, 2008).

As a social phenomenon, culture is a historical process, bases on material-moral values and norms, and is considered to be "the second nature" of a person. Its classical element is from chaos to order. Each period has its own culture. Today, culture is regarded as the result of the nurturing process.

These elements create the condition in which nurturing-based education turns into a personality-based education level. Using these elements in different stages of the education process positively affects the educational process of learners. 
The objective of the research is to learn the effects of creative ways of thinking of students and personal traits on their educational activities.

The hypothesis of the research. As known by everyone, creative tasks are vital for the improvement of the creative way of thinking. The research hypothesis is that in case creative tasks are used for the formation and development of personality, they can extraordinarily affect educational achievements.

\section{Method}

The experiment was carried out in Baku State University and Azerbaijan State Pedagogical University.196 students participated in the research process. The participants joined the research into two groups: the control group of 101 students and the experimental group of 94 students.

Practical training in the experimental groups was carried out in line with the requirements of Abdul Alizade's taxonomy, but this was not the same for the control groups. By the outlined objectives, the experiment was conducted with the second year students in the workshops and individual training during the Pedagogy course. The students were assigned creative tasks in a way that these tasks created a good condition to improve their creative ways of thinking and to develop personal traits. At the beginning and end of the experiment, the educational achievements of students depending on creative ways of thinking and personality development were evaluated via comparative analysis.

Criteria to measure the creative way of thinking: (Note: while determining the criteria to measure both the creative way of thinking and personality traits, the works by J. P. Guilford were referred to) He thought that the creative way of thinking is directly related to four dominant traits:

a) Originality, nontriviality, an ability to produce unusual ideas, obvious expression of intellectual innovations.

b) Semantic flexibility. This is the ability to observe objects from different perspectives, to find out new rules for the usage, and improve the functional application in practice.

c) Figurative adaptive flexibility. This means the ability to change the comprehension of an object in a way that hidden news features become visible.

d) Semantic spontaneous flexibility. This is the ability to have extraordinary ideas in indefinite situations (Qodfrua, 1992).

Criteria to measure the personality traits: J. P. Guilford thought that the followings are very important for individuals who want to improve their creative ways of thinking:

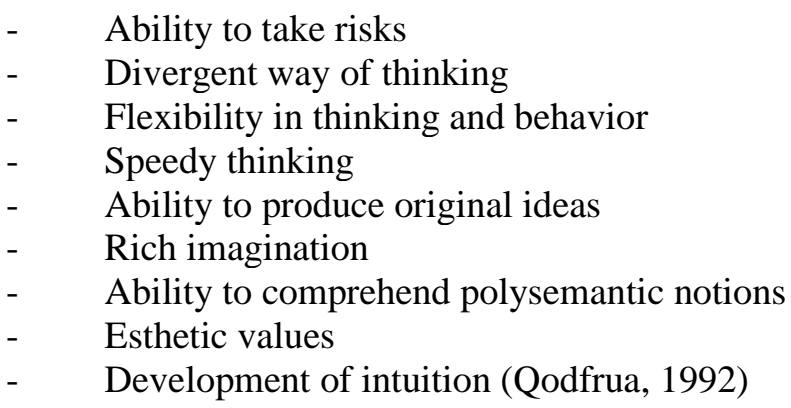


It is worth mentioning some points to improve the creative potentials of people:

a) Improving abilities to acquire new knowledge and skills, to collect and systemize information that is necessary for the creation of new things, as well as for the proper type of activities.

b) Creation of an atmosphere that leads to creativity. The key feature of this atmosphere is the lack of criticism in the creation of new ideas stage, and in its turn, it eliminates internal limitations that prevent observing problems from new perspectives.

c) Seeking analogies. If it is possible to see analogies between issues and other problems, even though they are not similar, it means that there are more chances for the creative solution of the problems.

The interpretation of the results. The creative tasks offer wide opportunities for the improvement of the creative way of thinking and the formation of personality traits. The implementation of the experiment and the analysis of the results have grounds to say so. The figures, which show the development dynamics of the creative ways of thinking and personality traits of students including their achievements within the experiment period, have been included in the article.

\section{Results}

The result of the comparison between two groups before the experiment:The development dynamics of the creative way of thinking of the students before the experiment is shown in Table 1. As it is seen in the Table, there was a slight difference. This shows the existence of the preliminary condition (the same or close inter-groups condition or levels) necessary to conduct the experiment.

Table 1.

The development dynamics of the creative way of thinking of the students before the experiment

\begin{tabular}{lrrrr}
\hline Group & Low & Medium & High & Total \\
\hline Control & 35 & 34 & 32 & 101 \\
Experimental & 33 & 32 & 29 & 94 \\
Total & 68 & 66 & 61 & 195 \\
\hline
\end{tabular}

The development dynamics of the creative way of thinking of the students before the experimentis given in the graph form. 


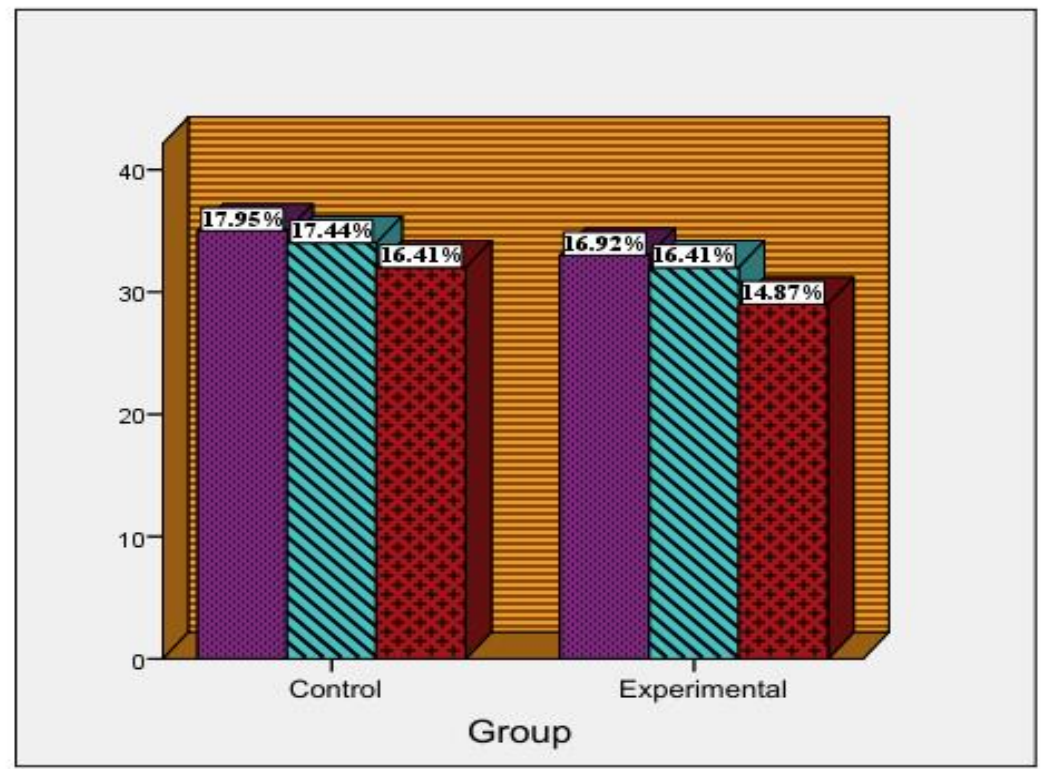

Figure 1. The development dynamics of the creative way of thinking.

The statistic description of the development dynamics of the personality traits of the students before the experimentis given in the Table 2. As it is seen in the Table, there was a slight difference. This shows the existence of the preliminary condition (the same or close inter-groups condition or levels) necessary to conduct the experiment.

Table 2.

The development dynamics of the personality traits of the students before the experiment

\begin{tabular}{crrrr}
\hline Group & Low & Medium & High & Total \\
\hline Control & 39 & 34 & 28 & 101 \\
Experimental & 35 & 33 & 26 & 94 \\
Total & 74 & 67 & 54 & 195 \\
\hline
\end{tabular}




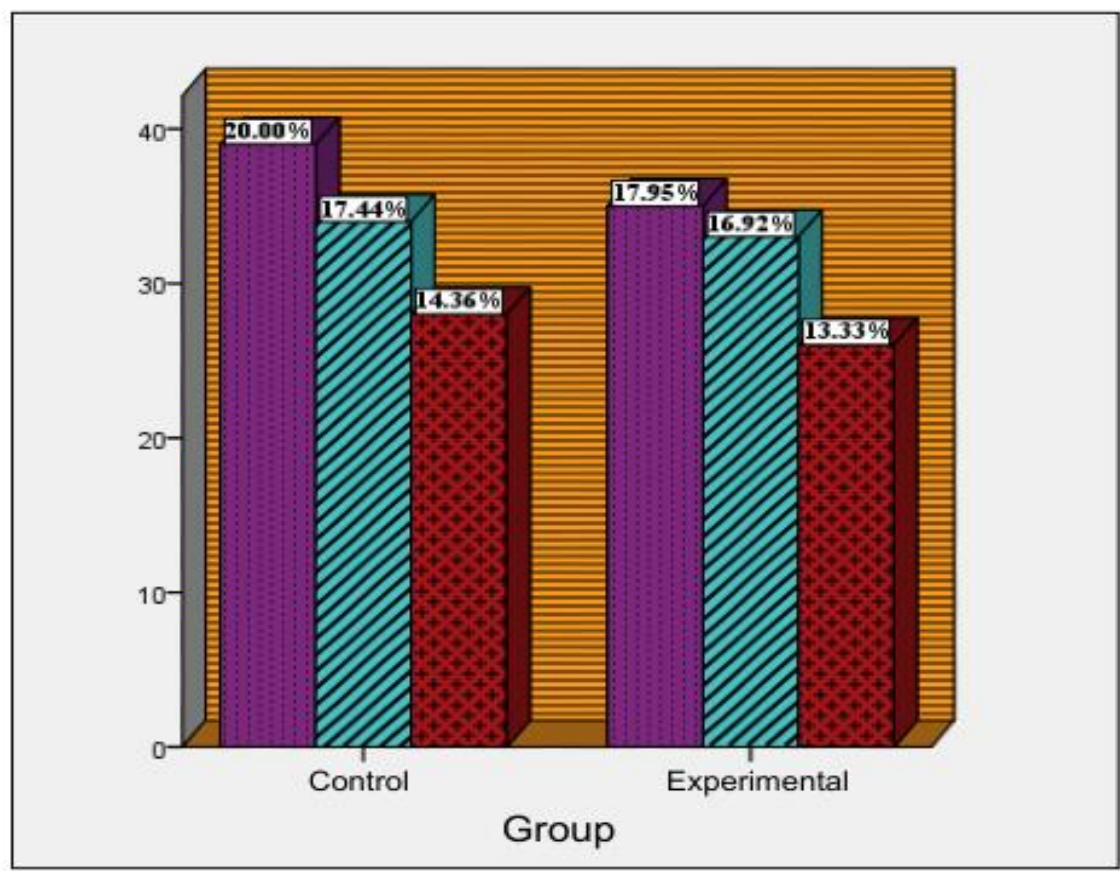

Figure 2. The development dynamics of the personality traits of students before the experiment.

The statistic description of the development dynamics of the academic achievements of students before the experiment is given in the Table 3. As it is seen in the Table, there was a slight difference. This shows the existence of the preliminary condition (the same or close inter-groups condition or levels) necessary to conduct the experiment.

\section{Table 3.}

The statistic description of the development dynamics of the academic achievements of students before the experiment

\begin{tabular}{|c|c|c|c|c|c|}
\hline Group & Low & Medium & High & Group & Total \\
\hline & Control & 22 & 45 & 34 & 101 \\
\hline & Experimental & 21 & 41 & 32 & 94 \\
\hline Total & & 43 & 86 & 66 & 195 \\
\hline
\end{tabular}




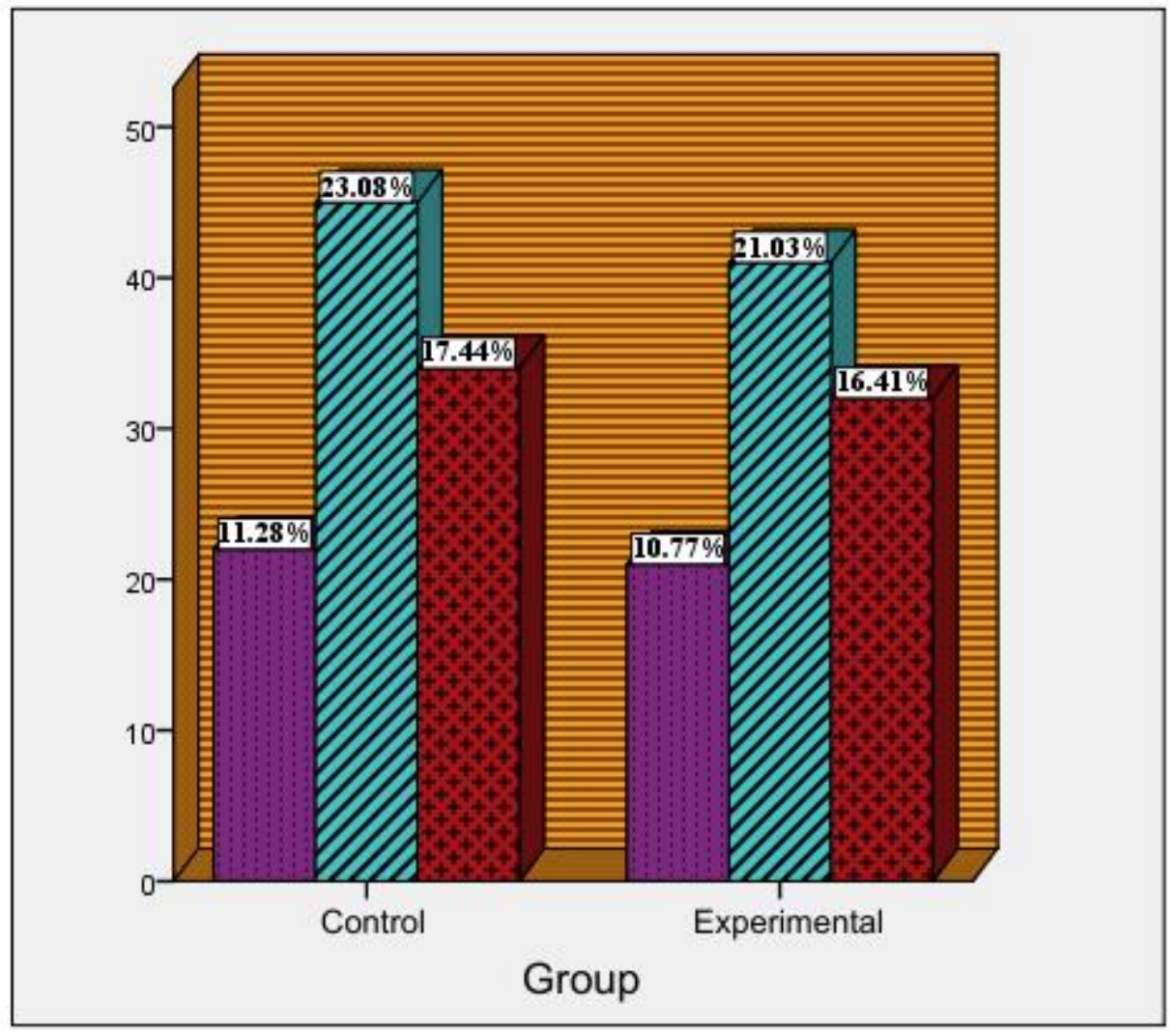

Figure 3. The development dynamics of the academic achievements of the students before the experiment.

T-test analysis was used to check whether the difference between groups on variables of "the development dynamics of the creative way of thinking of the students", "the development dynamics of the personality traits of students", and "the development dynamics of the academic achievements of the students" were meaningful or not from statistical point of view. The conclusion shows that there is no obvious difference between groups in the context of abovementioned elements. This means that as Sig is $\geq 0.05$, the present difference is meaningful on the 0.05 level. The variables for the creative way of thinking is $\mathrm{Sig}=0.913$, for the personality trait is $\mathrm{Sig}=0.910$, and for the academic achievements is $\mathrm{Sig}=0.987$. 


\section{Table 4.}

T-test for the creative way of thinking, personality traits, and the academic achievements

T-test for the creative way of thinking, personality traits, and academic achievements.

\begin{tabular}{|c|c|c|c|c|c|c|c|}
\hline \multirow[t]{2}{*}{ Variables } & \multirow[t]{2}{*}{$\mathrm{t}$} & \multirow[t]{2}{*}{ df } & \multirow{2}{*}{$\begin{array}{c}\text { Sig. } \\
(2- \\
\text { tailed) }\end{array}$} & \multirow{2}{*}{$\begin{array}{c}\text { Arithm } \\
\text { etic } \\
\text { mean } \\
\text { differe } \\
\text { nce }\end{array}$} & \multirow{2}{*}{$\begin{array}{l}\text { Stan- } \\
\text { dard } \\
\text { Deviati } \\
\text { on }\end{array}$} & \multicolumn{2}{|c|}{$\begin{array}{l}95 \% \\
\text { reliabilityinterval }\end{array}$} \\
\hline & & & & & & Low & High \\
\hline $\begin{array}{l}\text { the development dynamics of the creative } \\
\text { way of thinking }\end{array}$ & .110 & 193 & .913 & .01285 & .11705 & -.21801 & .24371 \\
\hline $\begin{array}{l}\text { the development dynamics of the personality } \\
\text { traits }\end{array}$ &. & 193 & .910 & -.01317 & .11577 & -.24150 & .21517 \\
\hline $\begin{array}{l}\text { the development dynamics of the academic } \\
\text { achievements }\end{array}$ & .017 & 193 & .987 & .00179 & .10635 & -.20797 & .21156 \\
\hline
\end{tabular}

The conclusion of the comparison between two groups: In the course of the experiment, planned tasks were conducted with the experimental groups, and under the rules, the existing condition remained unchanged in the control groups without any experimental factors. The comparison was made between the scores of the groups in the second stage after the experiment to determine whether the experimental factors had any effects or not.

Statistic description of the development dynamics of the creative way of thinking of the students is given in the Table below. From the Table, it is clear that the difference is more obvious in comparison with the first stage.

\section{Table 5.}

The development dynamics of the creative way of thinkingof the students after the experiment

\begin{tabular}{llrrrr}
\hline Group & Low & \multicolumn{2}{c}{ Medium } & High & \multicolumn{2}{c}{ Total } \\
\hline \multirow{4}{*}{ Total } & Control & 35 & 33 & 33 & 101 \\
& Experimental & 15 & 37 & 42 & 94 \\
\hline
\end{tabular}

The development dynamics of the creative way of thinking of the students after the experiment is given the Figure 4. 


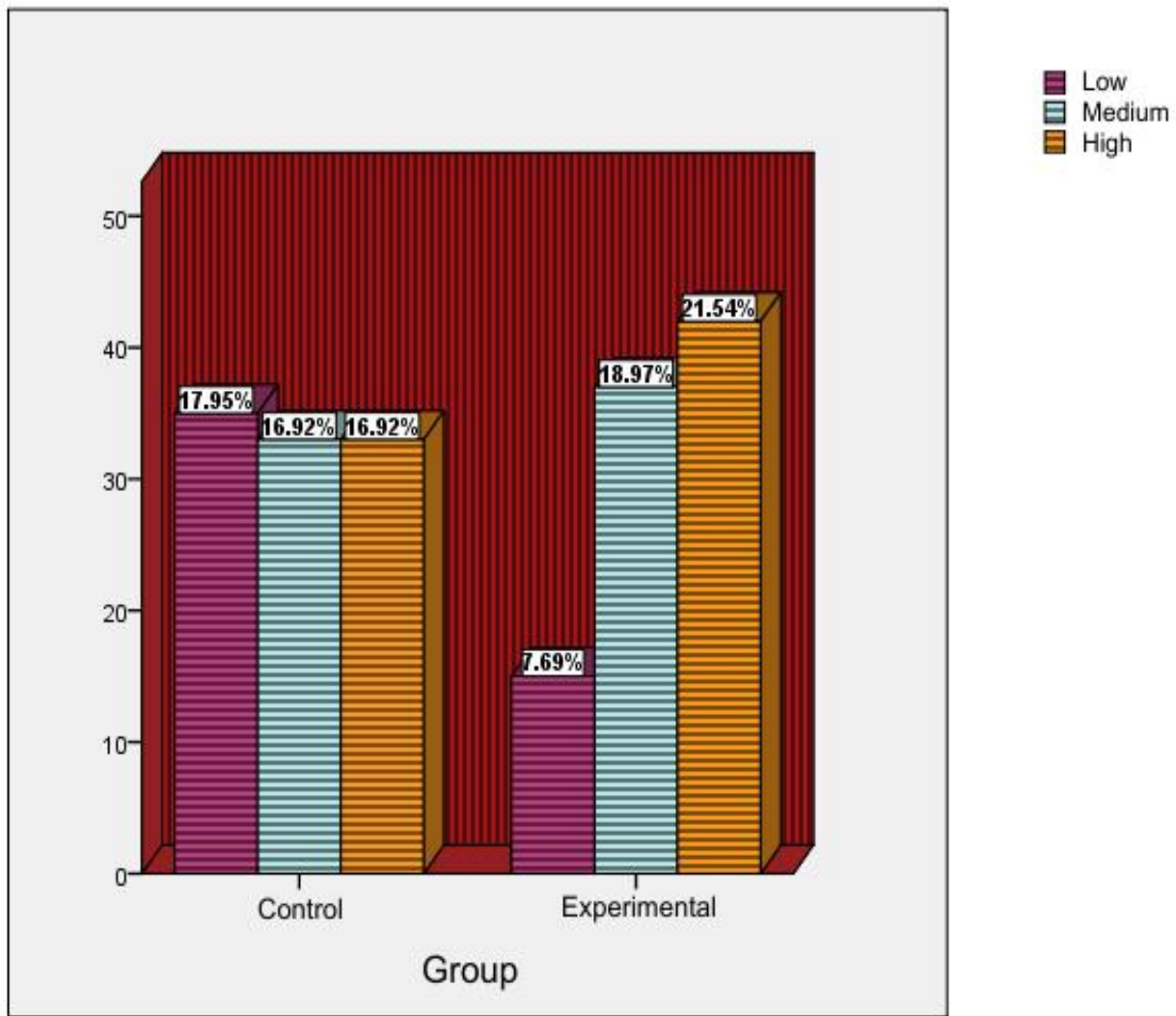

Figure 4. The development dynamics of the creative way of thinking of the students after the experiment

Statistic description of the development dynamics of the personality traits of the students is given in the Table below. From the Table, it is clear that the difference is more obvious in comparison with the first stage.

\section{Table 6.}

The development dynamics of the personality traits of the students after the experiment

\begin{tabular}{|c|c|c|c|c|}
\hline Group & Low & Medium & High & Total \\
\hline Control & 37 & 36 & 28 & 101 \\
\hline Experimental & 23 & 32 & 39 & 94 \\
\hline Total & 60 & 68 & 67 & 195 \\
\hline
\end{tabular}

The development dynamics of the personality traits of the students after the experiment is given the Figure 5. 


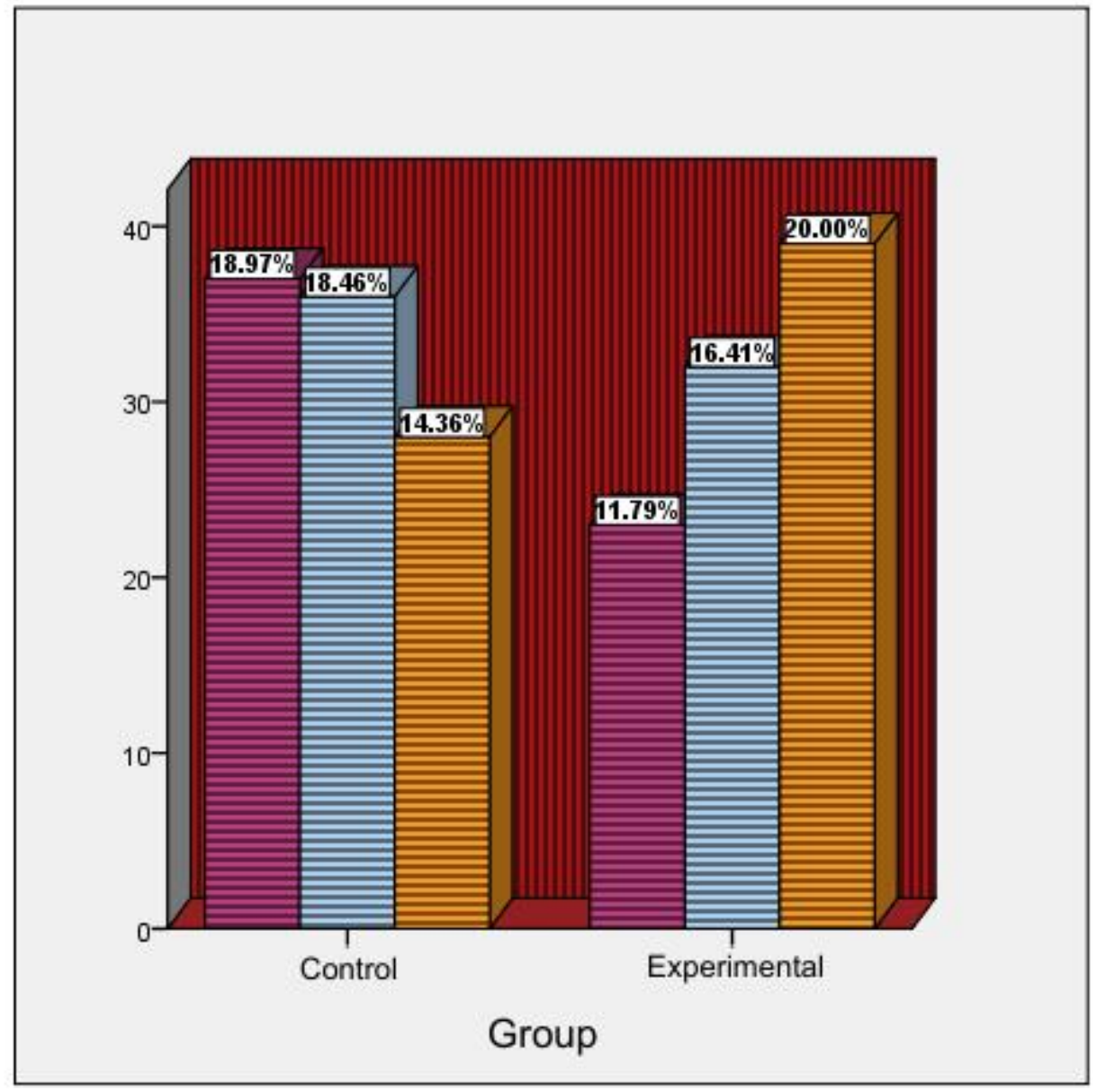

Figure 5. The development dynamics of the personality traits of the students after the experiment

Statistic description of the development dynamics of the academic achievements of the students is given in the Table below. From the Table, it is clear that the difference is more obvious in comparison with the first stage.

\section{Table 7.}

The development dynamics of the educational achievements of the students after the experiment

\begin{tabular}{|c|c|c|c|c|}
\hline Group & Low & Medium & High & Total \\
\hline Control & 20 & 46 & 35 & 101 \\
\hline Experimental & 6 & 48 & 40 & 94 \\
\hline Total & 26 & 94 & 75 & 195 \\
\hline
\end{tabular}

The development dynamics of the academic achievements of the students after the experiment is given in Figure 6. 


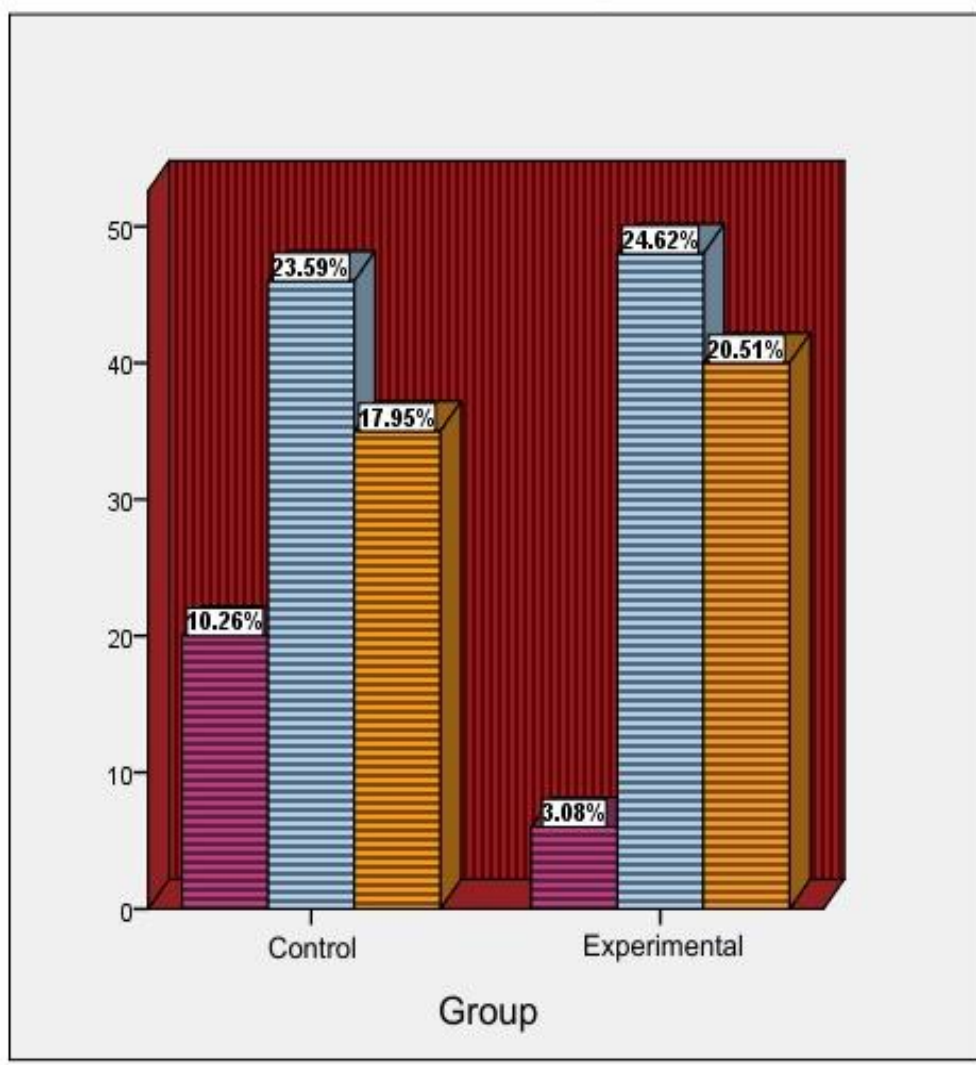

Figure 6. The development dynamics of the academic achievements of the students after the experiment

In the second stage of the experiment, T-test analysis was used to check whether the difference between groups on variables of "the development dynamics of the creative way of thinking of the students", "the development dynamics of the personality traits of students", and "the development dynamics of the academic achievements of the students" were meaningful or not from statistical point of view. The conclusions show that there were obvious differences between the groups. Thus, as Sig is $<0.05$, it can be said that the present difference is meaningful on 0.05 level. The variable for the creative way of thinking is Sig $=0.007$, for personality trait is $\mathrm{Sig}=0.025$, and for educational achievements is $\mathrm{Sig}=0.027$.

\section{Table 8.}

T-test for the creative way of thinking, personality traits, and the the academic achievements

\begin{tabular}{|c|c|c|c|c|c|c|}
\hline \multirow[t]{2}{*}{ Variables } & \multirow{2}{*}{$\mathrm{t} \quad \mathrm{df}$} & \multirow{2}{*}{$\begin{array}{c}\text { Sig. } \\
(2- \\
\text { tailed) }\end{array}$} & \multirow{2}{*}{$\begin{array}{l}\text { Arithm } \\
\text { etic } \\
\text { mean } \\
\text { differe } \\
\text { nce }\end{array}$} & \multirow{2}{*}{$\begin{array}{l}\begin{array}{c}\text { Stan- } \\
\text { dard } \\
\text { Deviati } \\
\text { on }\end{array} \\
\end{array}$} & \multicolumn{2}{|c|}{$\begin{array}{l}95 \% \text { reliability } \\
\text { interval }\end{array}$} \\
\hline & & & & & Low & High \\
\hline $\begin{array}{l}\text { the development dynamics of the creative } \\
\text { way of thinking }\end{array}$ & $\begin{array}{r}2.74 \\
9\end{array} 193$ & .007 & .30704 & .11168 & .08676 & .52731 \\
\hline $\begin{array}{l}\text { the development dynamics of the personality } \\
\text { traits }\end{array}$ & 2.26193 & .025 & .25932 & .11463 & .03323 & .48541 \\
\hline $\begin{array}{l}\text { the development dynamics of the academic } \\
\text { achievements }\end{array}$ & $\frac{2.22}{2} 193$ & .027 & .21319 & .09593 & .02398 & .40239 \\
\hline
\end{tabular}




\section{Discussion}

In Pedagogy, it has been proved that creative tasks play a very significant role in the development of the creative way of thinking. However, each period requires certain qualities that enable people to be successful in society. The formation and development of personality in the modern period is very important for the self-realization of people. Education processes provide good opportunities for the formation of these qualities.

Before the experiment, T-test analysis was used to check whether the difference between groups on variables of "the development dynamics of the creative way of thinking of the students", "the development dynamics of the personality traits of students", and "the development dynamics of the academic achievements of the students" was meaningful or not from statistical point of view. The conclusion showed that there was no obvious difference between groups in the context of above-mentioned elements.

There was no obvious difference between the groups from the mentioned indicators perspective. As Sig was $\geq 0.05$, the present difference was meaningful on the 0.05 level. The variables for the creative way of thinking was $\mathrm{Sig}=0.913$, for personality trait was $\mathrm{Sig}=0.910$, and for educational achievements was Sig=0.987.

After the experiment, T-test analysis was used to check whether the difference between groups on variables of "the development dynamics of the creative way of thinking of the students", "the development dynamics of the personality traits of students", and "the development dynamics of the academic achievements of the students" was meaningful or not from statistical point of view. The conclusions show that there were obvious differences between the groups. Thus, as Sig is $<0.05$, it can be said that the present difference is meaningful on 0.05 level. The variable for the creative way of thinking is $\mathrm{Sig}=0.007$, for personality trait is $\mathrm{Sig}=0.025$, and for educational achievements is Sig=0.027. By the obtained conclusions and T-test table, it can be said that experimental factors had serious effects over the experimental groups and resulted with the statistically meaningful differences between the groups in the second stage.

\section{References}

Alizadeh, A. A. (2001). New pedagogical thinking: ideas, principles, problems. Baku: Adiloglu, p. 162.

Alizade, A.A, Alizadeh H.A, Alizadeh S.R. (2019). Psychopedagogy. Textbook. Baku: Ecoprint. Bloom, B., et al. (1956). Taxonomy of Educational Objectives: The Classification of Educational Goals. New York: McKay.

Bloom, B. S. (1956). Taxonomy of educational objectives. Cognitive domain (Vol. 1). New York: McKay, 20-24.

Bloom, B. S. (1994). Reflections on the development and use of the taxonomy. In Rehage, Kenneth J.; Anderson, Lorin W.; Sosniak, Lauren A. (eds.). Bloom's taxonomy: A fortyyear retrospective. Yearbook of the National Society for the Study of Education. Chicago: National Society for the Study of Education.

Davydov, V.V. (1986). Problems of developing learning. Mockva. p. 240.

Gilford, J.P. (1967). The Nature of Human Intelligence. N.Y.: Davaid McKey Co., p 538.

Godfroix, J. (1992). What is Psychology: In 2 vols. T. 1: Per. from French.-M.: Mir, p.496.

Keatinge M. W. (1907). The Great Didactic Of John Amos Comenius, part II, London, Adam and Charles Black, p 326.

Krathwohl, D. R. (2002). A revision of Bloom's taxonomy: An overview. Theory into practice, 41(4), 212-218.

Mahmudova, R. M. (2018). Psychodynamic problems of education. Baku, Nurlar, p.312. 
Maslow, A.G.(1999). Motivation and Personality. St. Petersburg: Eurasia, p.478.

Piaget, J. (1969). Selected psychological works. Education, p. 659.

Vygotsky, L.S. (1934). Thinking and Speech. p. 362

Rustamov, F.A. (2006). History of Education / Pedagogical Thought in Foreign Countries. Textbook. Baku: Nurlar. p. 748. 